\title{
Phylogenetic Analysis of Streptomyces spp. Isolated from Soil Samples in Sulaimani Governorate
}

\author{
Syamand A. Qadir" ${ }^{1 *}$, Miran H. Qadir², Osama H. Shareef', Aryan M. Faraj' \\ ${ }^{1}$ Department of Medical Laboratory Science, Technical College of Applied Sciences, Sulaimani Polytechnic University, Sulaymaniyah, \\ Kurdistan Region, Iraq, ${ }^{2}$ Department of Horticulture, Collage of Agricultural Engineering Sciences, University of Raparin, Sulaymaniyah, \\ Kurdistan Region, Iraq
}

\author{
${ }^{*}$ Correspondence author: \\ Syamand A. Qadir, \\ Department of Medical \\ Laboratory Science, \\ Technical College of Applied \\ Sciences, \\ Sulaimani Polytechnic \\ University, \\ Sulaymaniyah, Kurdistan \\ Region, Iraq \\ E-mail: syamand.qadir@ \\ spu.edu.iq
}

Received: 05 June 2019

Accepted: 18 December 2019

Published: 30 June 2020

$\overline{\text { DOI }}$
10.25156/pti.v10n1y2020.pp18-24

\begin{abstract}
A B S T R A C T
Streptomyces species have been an important source of bioactive secondary metabolites and clinically useful for antibiotic production, including fosfomycin, daptomycin, oxytetracycline, streptomycin, and chloramphenicol. The main objective of this study was to isolate actinomycetes, especially Streptomyces from 8 soil samples that collected from two different places, which are districts in Sulaimani governorate, Kurdistan Region of Iraq. Totally, 30 diagnostic tests were carried out for representative of isolated Streptomyces depending on the color groups. The 16Sr DNA gene was sequenced, for ten isolated test strains were amplified with 2 universal primers after extraction of genomic DNA, only 8 of them were successfully sequenced. Phylogenetic analysis of 8 test strains carried out using base sequences of $16 \mathrm{Sr}$ DNA genes in the core genome. Four of isolated test strains were identified as a Streptomyces fulvissimus, and others were nominated as a Streptomyces anulatus. The obtained sequence data were compared with the sequence data of the closest related species in the international databases using EzTaxon Server program and (\%) similarities were determined. Finally, phylogenetic analysis indicated that isolated test strains were nominated as ( $\mathrm{HOO} 1, \mathrm{HOO} 2, \mathrm{HOO}$, and $\mathrm{HOO} 4)$, which recognized members of the $S$. anulatus and the similarity with their type strain is $99.93 \%$. Whereas, other four isolated test strains, including D001, D002, D003, and D004 recognized as members of the S. fulvissimus and similarity with their type strain is $100 \%$.
\end{abstract}

Keywords: Actinobacteria; Streptomyces; Antibiotic; $16 \mathrm{Sr}$ DNA and Diaminopimelic acid; Soil

\section{INTRODUCTION}

Actinobacteria are one of the most widely distributed groups of microorganisms in the world, particularly in the soil. Streptomyces species are belonging to the Actinobacteria class. They are recognized as gram-positive and aerobic soil bacteria that show filamentous growth from a single spore. As their filaments grow through tip extension and branching, they ultimately make a network of branched filaments called a substrate mycelium (Dyson, 2011). Biochemical analysis data were carried out to study Streptomyces (Williams et al., 1983; Kampfer et al., 1991) and also rRNA/DNA similarities were used by Witt and Stackebrandt (Witt and Stackebrandt, 1990). The member of the genus Streptomyces is filamentous bacteria, which protect soil from erosion during wind; cause remains the texture of the soil and ability to survive during alkaline and dry condition (Vetsigian et al., 2011). In general, Streptomyces is described as the largest genus of Actinobacteria (Yousif et al., 2015). More than 770 species of Streptomyces have been recognized (Bunyapaiboonsri et al., 2016). Back to year (1943), species of Streptomyces for the $1^{\text {st }}$ time were introduced by Waksman and Henrici (Waksman and
Henrici, 1943). Streptomyces are able to grow in various environments (Maleki et al., 2013). Soil is the best habitat for reproduction and surviving of Streptomyces (Mokrane et al., 2013). Species of Streptomyces greatly dispersed in soil, water, and other environments. They are the largest diversity bacteria in the soil, including $40 \%$ of soil bacteria. Some biological, physical, and chemical factors are effects on the distribution of Streptomyces in an ecosystem, including temperatures, $\mathrm{pH}$, salinity, moisture, soil texture, food stress, and climate (Hasani et al., 2014). Synthesizing of bioactive secondary metabolites and complex developmental cycle are common characters of Streptomyces. This genus normally produces $1 / 3$ of commercial antibiotics that are available nowadays. Moreover, antiparasitic, immunosuppressant, antibacterial, and antifungal compounds have been selected as secondary metabolism products of Streptomyces (Omura, 1992; Hopwood, 2007; Newman and Cragg, 2007; Goodfellow and Fiedler, 2010; Mao et al., 2011). Streptomyces species have a dual role in the source of bioactive secondary metabolites, especially antibiotics that have a contribution to human health, as an antibiotic producer microorganism, Streptomyces accounting for perhaps $70 \%$ of the antibiotic compounds so far discovered (Lewin et al., 2016; Bérdy, 
2005). Renewing recognition, the value of this genus is an attempt to understanding the ecology of Streptomyces for drug discovery (Asamizu et al., 2015).

\section{MATERIALS AND METHODS}

\section{Collection of Soil Samples}

Different locations such as mountains, valleys, and lakesides were chosen to obtain soil samples. They were obtained from different sites of Pshdar and Ranya/Sulaimani governorate. They were collected in a depth of $20 \mathrm{~cm}$ after removing nearly $5 \mathrm{~cm}$ of the surface soil and put in a sterile container. The samples were stored in sterile plastic bags before being transported to the lab, then they kept in the refrigerator at $4^{\circ} \mathrm{C}$ till the microbial assays performed.

\section{Physiochemıcal Characterıstics of Soil Samples and Isolation Process}

Physicochemical characters of soil samples ( $\mathrm{pH}$, moisture, and organic matter content) were measured quickly after samples brought to the laboratory (Reed and Cumming, 1945). The bacterium was maintained by cultured at approximately weekly intervals on starch-casein agar (Küster, 1964) and raffinose-histidine agar (Vickers et al., 1984). The plates were inoculated inside of the laminar flow cabinet and they were allowed to dry, then they inverted position and incubated at $28^{\circ} \mathrm{C}$ for 2 weeks. After incubation, the desired colonies were distinguished and separated from other bacteria on the basis of colony morphology, pigmentation, and ability to produce a different color of aerial hyphae and substrate mycelium on starch-casein agar and raffinose-histidine agar plates [Table 1]. Then, they were isolated and coded according to locality. Furthermore, modified Bennett's agar was used to get a pure colony of desired strains; after that, they were stored in a sterile $2 \mathrm{ml}$ Eppendorf tube containing 20\% glycerol and stored at $-80^{\circ} \mathrm{C}$.

\section{Biochemical Analysis of Desired Test Strains}

The isolated test strains were examined for these tests including (Nutritional test: Capability of test strains to use ten different nitrogen carbon sources for growth and energy, degradation of sterilized: Casein, starch, and gelatin, capability of isolates to grow in different chemical inhibitors: Antibiosis, antimicrobial activity, and test strains were evaluated for their antimicrobial action against Grampositive bacteria [Staphylococcus aureus and Bacillus subtilis] and Gram-negative bacteria [Escherichia coli, Pseudomonas fluorescens] and fungi including Candida sp.) [Table 2].

\section{Molecular Characterization of the Isolated Test Strains Isolation of genomic DNA}

Genomic DNA test was examined very accurately, and carry out on eight test strains representatives of color
Table 1: List of isolated Streptomyces species, type of isolation medium, and source of test strains

\begin{tabular}{lll}
\hline Strains & Source & Isolation medium \\
\hline D001 & Delo & Starch casein agar \\
D002 & Nuraddin & Starch casein agar \\
D003 & Darband & Raffinose-histidine agar \\
D004 & Piran & Raffinose-histidine agar \\
H001 & Halsho & Starch casein agar \\
H002 & Darwina & Raffinose-histidine agar \\
H003 & Qamtaran & Starch casein agar \\
H004 & Dukan & Starch casein agar \\
\hline
\end{tabular}

Table 2: List of the diagnostic tests used for identification of isolated microorganisms

\begin{tabular}{llll}
\hline No & Tests & No & Tests \\
\hline 1. & Casein & 16. & Potassium nitrate \\
2. & Raffinose & 17. & Tyrosine \\
3. & Gelatin & 18. & Sodium chloride $7 \%$ \\
4. & Dextran & 19. & Crystal violet $0.0001 \%$ \\
5. & Fructose & 20. & Ampicillin $(20 \mathrm{mg})$ \\
6. & Maltose & 21. & Vancomycin $(30 \mathrm{mg})$ \\
7. & Mannose & 22. & Penicillin $(30 \mathrm{mg})$ \\
8. & Starch & 23. & Gentamycin $(10 \mathrm{mg})$ \\
9. & Sucrose & 24. & Rifampin $(5 \mathrm{mg})$ \\
10. & Lactose & 25. & Erythromycin $(15 \mathrm{mg})$ \\
11. & Mannitol & 26. & Escherichia coli \\
12. & Histidine & 27. & Pseudomonas fluorescens \\
13. & Sodium citrate & 28. & Bacillus subtilis \\
14. & Sodium acetate & 29. & Candida sp. \\
15. & S. propionate & 30. & Staphylococcus aureus \\
\hline
\end{tabular}

grouping were subject to DNA isolation. The method for DNA isolation of the isolated test strains is described by Pitcher (Pitcher et al., 1989). DNA isolation method with DNA isolation kit (Invitrogen, Pure Link (R) Genomic DNA Kit) was used.

\section{DNA isolation control}

About $1 \%$ agarose gel (60 $\mathrm{ml} 1 \mathrm{X}$ TBE buffer, $0.6 \mathrm{~g}$ agarose) supplemented with ethidium bromide $4 \mu \mathrm{l}$ was prepared and used to control the presence of extracted DNA. The prepared gel was loaded by adding a mixture of $3 \mu \mathrm{l}$ total genomic DNA and $2 \mu$ of ethidium bromide. After DNA loaded, agarose gel placed in the electrophoresis tank and run at 100 volts for 45 min. The DNA band was checked under UV transilluminator (Vilber Lourmat, UV) and captured a photograph.

\section{Polymerase chain reaction (PCR) amplification of 16s rDNA gene}

After isolation of genomic DNA, the16S rRNA gene was amplified by two universal primers 27f, (5'-AGA GTT TGA TCM TGG CTC AG-3) and 1525R, (5'- AAG GAG GTG WTC CAR CC-3'). Stock solutions were prepared for the PCR reaction by sterile $\mathrm{ddH}_{2} \mathrm{O}$. They were separated in sterile Eppendorf tubes in small quantities 25-100 $\mu \mathrm{l}$ 
to remove the risk of contamination and stored at $-20^{\circ} \mathrm{C}$ until use. PCR procedures for the $16 \mathrm{~S}$ rDNA genes were carried out at a Thermal Cycler (MyGenie-96 Gradient Thermal Cycler, Korea) in a $0.2 \mathrm{ml}$ PCR tube.

\section{Phylogenetic analysis of $16 s$ DNA sequence}

The $16 \mathrm{~S}$ rDNA gene was subjected to sequencing with methods supplied by Chun and Goodfellow (Chun and Goodfellow, 1995). The obtained PCR product were sequenced with three primers, including 518F, (5'-CCAGCAGCCGCGGTAAT-3), 800R (5'-TACCAGGGTATCTAATCC-3'), and $\mathrm{Mg} 5 \mathrm{f}$ (5'-AAACTCAAAGGAAT'TGACGG-3). DNA sequencing of $16 \mathrm{~S} \mathrm{rDNA}$ of eight isolated test strains was carried out by MacroGen Company (Netherland). The complete $16 \mathrm{~S}$ rDNA sequences of all isolates strain were analyzed with Chromas version 1.7.5 (McCarthy, School of Health Sciences, and Griffith University, Queensland, Australia) program. The DNA sequencing was calculated aligned with the previously deposited sequences, the similarities and most closely related with their type of strains using EzTaxon server (Kim et al., 2012). The sequences of isolates type of strains were bring from GenBank and aligned using (CLUSTAL W in MEGA6) program (Tamura et al., 2013). Construction of the phylogenetic trees was achieved using the neighbor-joining (Saitou and Nei, 1987), maximumlikelihood (Felsenstein, 1981), maximum-parsimony (Fitch, 1971), and algorithms in the MEGA6 program (Tamura et al., 2013). The topology of the phylogenetic trees was analyzed by the bootstrap resampling method of Felsenstein (Felsenstein, 1985) with 1000 replicates.

\section{Chemotaxonomic Characterization}

The strains were subjected for morphological and chemotaxonomic properties of the typical for genus Streptomyces (Trujillo, 2012). Chemotaxonomy is a biological method for studying the chemical difference in microbial cell and the use of chemical features in the classification and identification of bacteria, including Streptomyces and it is a crucial technique. One of the isolated test strains was inoculated in glucose yeast malt extract broth (ISP6) in flask with shaken $180 \mathrm{rpm}$ at $28^{\circ} \mathrm{C}$ for 1 week to determine the chemotaxonomic study. Cells were collected by centrifugation and washed 2 times in sterile distilled water and re-centrifuged and freeze at $-80^{\circ} \mathrm{C}$, after that lyophilized at lyophilization for $16 \mathrm{~h}$ to getting dried bacterial cell mass. Then, chemotaxonomic studies, including sugar analysis and diaminopimelic acid (DAP), have been done.

\section{RESULTS}

\section{Physiochemical Parameter of Soil Samples}

The physiochemical results of the soil samples were investigated, including organic $\mathrm{pH}$ matter content and moisture contents of the soil samples. The highest $\mathrm{pH}$ (8.63) was recorded in soil sample number D001 in Piran location. The highest amount of organic matter content $(10.2 \%)$ was recorded in soil sample number H003 that collected from eSewa. The highest amount of moisture content (9.13) was recorded in the soil sample number H002 that collected from Darband Table 3.

\section{Distribution and Numbers of Streptomyces}

Starch casein agar and raffinose-histidine agar were used to isolate Streptomyces bacteria (Atalan, 1993). The soil sample was inoculated after doing serial dilution and the Petri plates prepared for the isolation process. After inoculation, they incubated at $28^{\circ} \mathrm{C}$ for 14 days. Eight pure strains were isolated by streak plate method and some of the isolation Petri plates are shown in Figure 1.

\section{Phenotypic Characterization}

Traditional identification tests such as biochemical, carbon source, nitrogen source, chemical inhibitor, temperature, antibiotics, morphology, pigmentation, and growth tests were used for both identification and numerical analysis. Total eight selected test strains were examined for 30 tests [Table 4 and Figures 2 and 3].

\section{Genomic DNA Extraction}

The genomic DNA of eight test strains was extracted using a specific method that was described by (Pitcher et al., 1989) and DNA isolation kit (Invitrogen, Pure Link (R) Genomic DNA). The extracted total genomic DNA was loaded on agarose gel electrophoresis and shown in Figure 4.

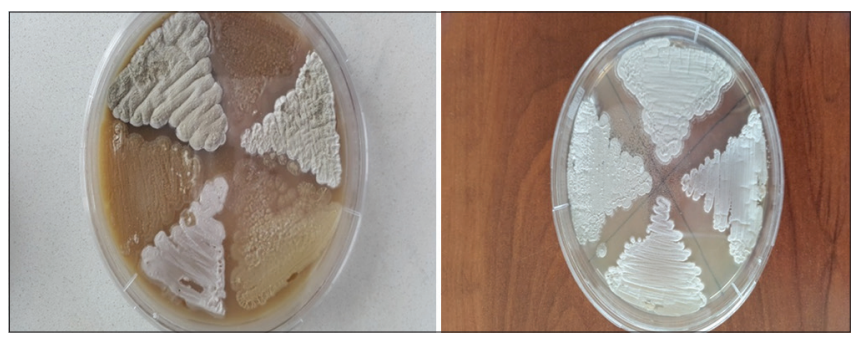

Figure 1: Colony appearance of Streptomyces on plates of starchcasein agar and Bennett's agar

Table 3: pH, moisture, and organic matter content of collected soil samples

\begin{tabular}{lcccc}
\hline Number & Isolated strain & $\mathrm{pH}$ & $\begin{array}{c}\text { Organic } \\
\text { content }\end{array}$ & $\begin{array}{c}\text { Moisture } \\
\text { content }\end{array}$ \\
\hline 1. & $\mathrm{D} 001$ & 8.63 & 8.21 & 2.60 \\
2. & $\mathrm{D} 002$ & 7.84 & 7.27 & 5.23 \\
3. & $\mathrm{D} 003$ & 7.33 & 8.37 & 5.50 \\
4. & $\mathrm{D} 004$ & 7.27 & 6.43 & 5.27 \\
5. & $\mathrm{H} 001$ & 8.44 & 5.53 & 3.57 \\
6. & $\mathrm{H} 002$ & 7.35 & 2.77 & 9.13 \\
7. & $\mathrm{H} 003$ & 8.55 & 10.20 & 5.45 \\
8. & $\mathrm{H} 004$ & 7.97 & 5.83 & 5.67 \\
\hline
\end{tabular}




\section{PCR Product of 16S rDNA Genes}

The 16S rDNA gene region for eight test strains was amplified using the gradient PCR with the universal primers $27 \mathrm{f}$ and $1525 \mathrm{r}$. The size of $16 \mathrm{~S} \mathrm{rDNA}$ region was average 1500 base pairs. The $16 \mathrm{~S}$ rDNA bands that amplified by PCR are seen on agarose gel electrophoresis [Figure 5].

Phylogenetic Tree and Analysis of 16S rDNA Sequence The 16S rDNA genes region were amplified by QIA quick PCR Purification Kit; then, they sequenced with primers 27f, 800r, and MG5f. EzTaxon server and (\%) similarities were used for comparison of obtained sequence data with the sequence data of the closest related species in the international databases. The dendrogram was generated to determine phylogenetic positions of test isolated strains and their relations with $16 \mathrm{~S}$ rDNA sequence data [Figure 6].

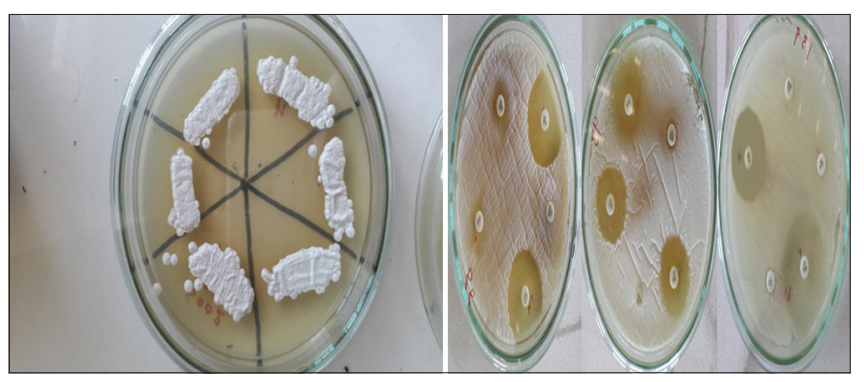

Figure 2: Antimicrobial activity of isolated strain against pathogenic bacteria and fungi with Antibiotic resistance tests

Table 4: Data obtained for biochemical analysis of representative of Streptomyces strains

\begin{tabular}{|c|c|c|c|c|c|c|c|c|}
\hline No. of strain tests & D001 & D002 & D003 & D004 & $\mathrm{H} 001$ & $\mathrm{H} 002$ & $\mathrm{H} 003$ & $\mathrm{HOO4}$ \\
\hline \multicolumn{9}{|l|}{ Nutritional tests } \\
\hline \multicolumn{9}{|c|}{ Growth on sole carbon source $(1 \%, w / v)$} \\
\hline Dextran & + & - & - & + & - & + & - & - \\
\hline Fructose & + & + & + & + & + & + & + & - \\
\hline Lactose & - & - & - & - & - & - & - & - \\
\hline Mannose & - & - & + & - & + & + & + & + \\
\hline Raffinose & + & + & - & + & + & - & - & - \\
\hline Sucrose & - & - & + & - & - & - & - & + \\
\hline Maltose & + & - & + & - & + & + & + & - \\
\hline Mannitol & - & + & - & + & + & + & - & + \\
\hline \multicolumn{9}{|c|}{ Growth on sole carbon source $(0.1 \%, w / v)$} \\
\hline Sodium acetate & + & - & - & + & - & - & - & - \\
\hline Sodium citrate & + & - & - & - & + & - & + & - \\
\hline Sodium propionate & + & + & + & + & + & + & + & - \\
\hline \multicolumn{9}{|c|}{ Growth on sole nitrogen source $(0.1 \% \mathrm{w} / \mathrm{v})$} \\
\hline Histidine & + & + & + & + & + & + & + & + \\
\hline $\mathrm{KNO} 3$ & + & + & - & + & + & - & + & + \\
\hline Tyrosine & - & + & + & - & + & - & + & + \\
\hline \multicolumn{9}{|l|}{ Degradation tests } \\
\hline Casein & + & - & + & - & - & + & - & + \\
\hline Starch & + & - & - & - & + & - & + & - \\
\hline Gelatin & + & - & + & - & - & + & - & + \\
\hline \multicolumn{9}{|c|}{ Tolerance tests } \\
\hline \multicolumn{9}{|c|}{ Resistance to chemical inhibitors } \\
\hline Sodium chloride $7 \%$ & + & - & + & - & - & - & + & - \\
\hline Crystal violet $0.0001 \%$ & - & + & - & - & + & + & - & - \\
\hline \multicolumn{9}{|l|}{ Resistance to antibiotics } \\
\hline Amoxicillin AMC (30 mg) & + & + & + & + & + & + & + & + \\
\hline Rifampicin RA (5 mg) & - & + & + & + & - & - & - & + \\
\hline Ampicillin SAM (20 mg) & + & - & + & - & + & + & + & + \\
\hline Gentamycin CN (10 mg) & - & + & - & - & - & - & - & - \\
\hline Erythromycin E (15 mg) & + & + & + & - & + & + & + & + \\
\hline $\begin{array}{l}\text { Amoxicillin AMC (30 mg) } \\
\text { Antimicrobial activity tests }\end{array}$ & + & - & + & + & + & + & + & + \\
\hline Escherichia coli & + & + & + & - & + & + & + & + \\
\hline Staphylococcus aureus & + & - & + & + & + & + & + & + \\
\hline Candida sp. & - & + & + & - & + & + & + & - \\
\hline Pseudomonas fluorescens & + & - & + & + & + & - & + & + \\
\hline Bacillus subtilis & + & + & + & - & - & - & - & - \\
\hline
\end{tabular}




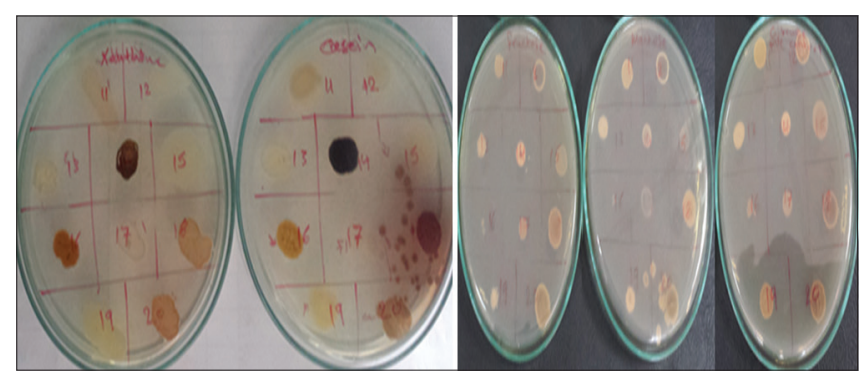

Figure 3: Nutritional source for isolated strain including carbon and nitrogen source

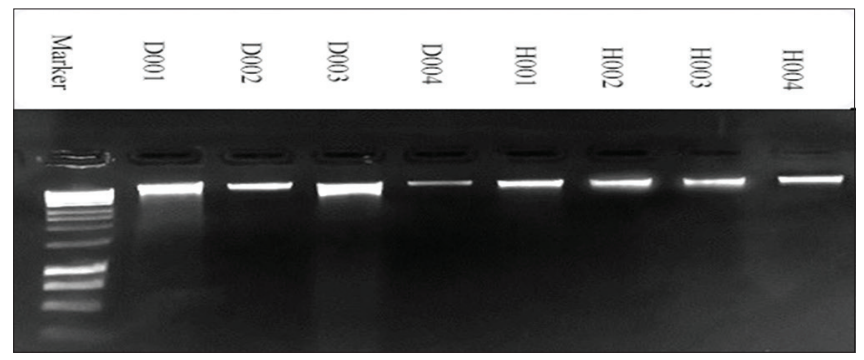

Figure 4: Whole genomic DNA bands of 8 test strains on 1\% agarose gel electrophoresis image (left side is marker 1500 bp DNA ladder)

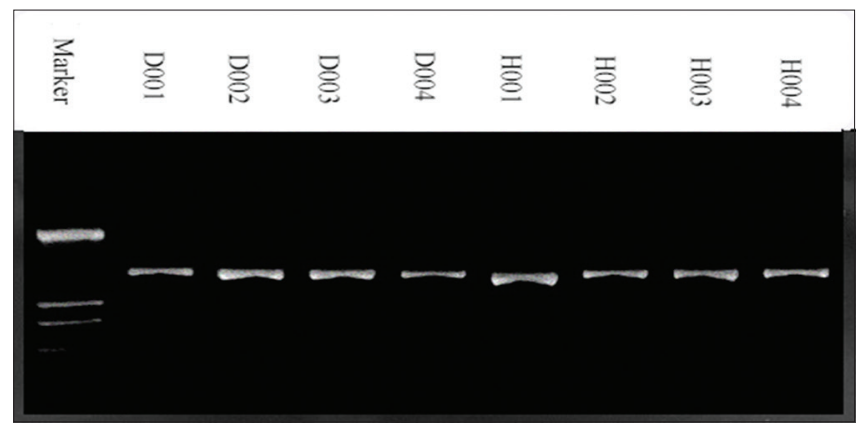

Figure 5: Polymerase chain reaction amplified product of the 16S rDNA gene region was loaded using 1.5\% agarose GEL electrophoresis (left side is marker 1500 bp DNA ladder)

The dendrogram was drawn using the neighborhoodjoining algorithm and the evolutionary distance matrix (Jukes and Cantor, 1969). MEGA6 package program was used for phylogenetic analyzes (Tamura et al., 2013). The phylogenetic trees bootstrap analysis created according to Felsenstein (Felsenstein, 1985) for 1000 replicates. Kitasatospora nipponensis HKI 0315T (AY442263) used as an outgroup for all strains of Streptomyces dendrograms as a result of phylogenetic analysis of sequence data, 8 isolate strains were identified as Streptomyces spp.

\section{Chemotaxonomic Analysis}

Chemotaxonomic analyses were performed to determine the characteristic chemical properties of the isolates. These analyzes include DAP and sugar analyzes. The one-dimensional thin-layer chromatography was used to determine DAP type in the cell wall of the test strain and

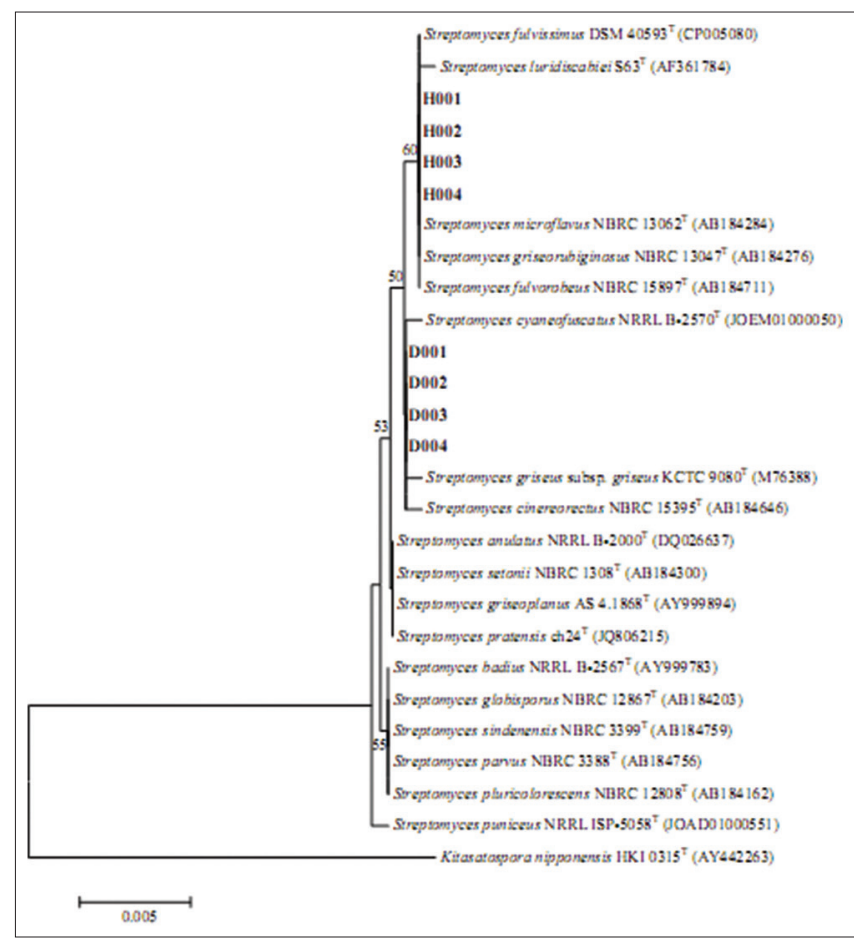

Figure 6: Phylogenetic dendrogram shows the relation of 8 test strains of Streptomyces regarding base sequence of 16S rDNA gene. Dendrogram produced neighbor-joining algorithms and numbers at nodes indicate the level of bootstrap support (\%), only value $\geq \mathbf{5 0} \%$ is shown. GenBank accession numbers are given in parentheses. Bar 0.005 substitutions per nucleotide position

compared with the standard A2pm solution. The result shows that test strain Streptomyces contains the LL-A2pm content and whole-cell sugar profile contains glucose.

\section{DISCUSSION}

Soil is an ecological treasury with many organisms living together and some of them producing useful natural products, including antibiotics. The isolated strains showed arrange of phylogenetic, morphological properties, and chemotaxonomic content. They classified that are belong to the genus Streptomyces (X-L, 2012). Pshdar and Ranya are two of the places that have not been investigated for isolation of Streptomyces and other Actinobacteria genera. In this study, we tried to identify the active strains of Streptomyces species. Ranya is the place that has not been investigated the soils for isolation of Streptomyces and other Actinobacteria genera. Hence, it was really necessary to isolate Streptomyces from the soil sample there because of recovering new Streptomyces species producing a new antimicrobial compound. The physicochemical characters of soil samples affected the recovery of Streptomyces and other bacteria on selective media. However, the number of soil Streptomyces were detected and different based on soil use and also parallel with soil $\mathrm{pH}$. Watkins reported that 
organic matter content of the soil correlates with land use and $\mathrm{pH}$, but does not correlate with recovery of Streptomyces (Watkins, 2013). Antony-Babu et al. suggested that the numerical analysis result of the color group supported the visual display of data as dendrograms posed and show the recognition of taxa regards to similar color characteristics (Antony-Babu et al., 2010). Some researchers suggested that the ability to separate unknown Streptomycetes to color groups, which can be equated with species-groups (Atalan et al., 2000; Sembiring et al., 2000) (Tan et al., 2006). Identification of bacterial strains is still a difficult subject for microbiologist despite the development of molecular biology techniques and the development of kits that are commercially available phenotype-based identification tests. Since the 16S rRNA gene is ubiquitous, stable, conserved, and poorly subject to horizontal gene transfer, it is an effective molecular marker for the identification of bacteria. It is well known that analyses of $16 \mathrm{~S}$ rRNA gene sequence of the strains are a fundamental technique for archaea and bacteria and are being used for the identification with the classification of the prokaryotes (Olsen and Woese, 1993) (Stackebrandt et al., 2002). Hence, sequencing and phylogenetic analysis of the $16 \mathrm{~S} \mathrm{rDNA}$ genes is easy and reliable method to classify and identify of bacterial isolates at various taxonomic levels. Moreover, the almost complete 16S rRNA gene sequence was compared with the corresponding sequences of representative members of color groups using MEGA (Altschul et al., 1997) and the results revealed the highest similarity $99.93 \%$. D001, D002, D003, and D004 were identified Streptomyces anulatus. While, (H001, H002, H003, and H004) strains were identified with Streptomyces fulvissimus at 100\% similarity. In conclusion, the phylogenetic analysis based on the sequencing of $16 \mathrm{~S}$ rRNA gene revealed that 8 test strains belong to genus Streptomyces and have high sequence similarity to Streptomyces.

\section{REFERENCES}

Altschul, S. F., T. L. Madden, A. A. Schaffer, J. Zhang, Z. Zhang, W. Miller and D. J. Lipman. 1997. Gapped BLAST and PSI-BLAST: A new generation of protein database search programs. Nucleic Acids Res. 25: 3389-3402.

Antony-Babu, S., J. E. M. Stach and M. Goodfellow. 2010. Computerassisted numerical analysis of colour-group data for dereplication of streptomycetes for bioprospecting and ecological purposes. Antonie Van Leeuwenhoek. 97: 231-239.

Asamizu, S., T. Ozaki, K. Teramoto, K. Satoh and H. Onaka. 2015. Killing of mycolic acid-containing bacteria aborted induction of antibiotic production by Streptomyces in combined-culture. PLoS One. 10(11): 1-17.

Atalan, E. 1993. Selective isolation, characterisation and identification of some Streptomyces species. Biosci. Biotech. Res. Asia. 14(4): 1401-1407.

Atalan, E., G. P. Manfio, A. C. Ward, R. M. Kroppenstedt and M. Goodfellow. 2000. Biosystematic studies on novel streptomycetes from soil. Antonie Van Leeuwenhoek. 77: 337-353.
Bérdy, J. 2005. Bioactive microbial metabolites. J. Antibiot. 58(1): 1-26.

Bunyapaiboonsri, T., S. Lapanun, S. Supothina, P. Rachtawee, S. Chunhametha, C. Suriyachadkun, T. Boonruangprapa, P. Auncharoen, C. Chutraku and V. Vichai. 2016. Polycyclic tetrahydroxanthones from Streptomyces chrestomyceticus BCC 24770. Tetrahedron. 72(5): 775-778.

Chun, J. and M, Goodfellow. 1995. A phylogenetic analysis of the genus Nocardia with 16 S rRNA gene sequences. Int. J. Syst. Bacteriol. 45: 240-245.

Cui, X. L. 2012. Streptomonospora. In : Goodfellow, M., P. Kämpfer, H. J. Busse, M. E. Trujillo, K. I. Suzukim, W. Ludwig and W. B. Whitman, editors. Bergey's Manual of Systematic Bacteriology. $2^{\text {nd }}$. Vol. 5. Springer, Berlin, Germany. p1908-1814.

Dyson, P. 2011. Streptomyces: Molecular Biology and Biotechnology. V. Press, Poole, UK.

Felsenstein, J. 1981. Evolutionary trees from DNA sequences: A maximum-likelihood approach. J. Mol. Evol. 17: 368-376.

Felsenstein, J. 1985. Confidence limits on phylogenies: An approach using the bootstrap. Evolution. 39(4): 783-791.

Fitch, W. 1971. Towards designing a course of evolution: Minimum change for a specific tree topology. Syst. Zool. 20: 406-416.

Goodfellow, M. and H. P. Fiedler. 2010. A guide to successful bioprospecting: Informed by actinobacterial systematics. Antonie Van Leeuwenhoek. 98: 119-142.

Hasani, A., A. Kariminik and K. Issazadeh. 2014. Streptomycetes : Characteristics and their antimicrobial activities. Int. J. Adv. Biol. Biomed. Res. 2(1): 63-75.

Hopwood, D. 2007. Streptomyces in Nature and Medcine. Oxford University Press, New York.

Jukes, T. H. and C. Cantor. 1969. Evolution of protein molecules. In: Mammalian Protein Metabolism. Academic Press, New York. p21-132.

Kampfer, P., M. Steiof and W. Dott. 1991. Microbiological characterization of a fuel oil contaminated site including numerical identification of heterotrophic water and soil bacteria. Microb. Ecol. 21: 227-251.

Kim, O. S., Y. J. Cho, K. Lee, S. H. Yoon, M. Kim, H. Na, S. C. Park, Y. S. Jeon, J. Lee, H. Yi, S. Won and Chun. 2012. Introducing EzTaxon-e: A prokaryotic 16S rRNA gene sequence data base with phylotypes that represent uncultured species. Int. J. Syst. Evol. Microbiol. 62: 716-721.

Küster, E. and S. T. Williams. 1964. Selection of media for isolation of streptomycetes. Nature. 202: 928-929.

Lewin, G. R., C. Carlos, M. G. Chevrette, H. A. Horn, B. R. McDonald, R. J. Stankey, B. G. Fpox and C. Currie. 2016. Evolution and ecology of actinobacteria and their bioenergy applications. Annu. Rev. Microbiol. 70: 235-254.

Maleki, H., A. Dehnad, S. Hanifian and S. Khani. 2013. Isolation and molecular identification of Streptomyces spp. with antibacterial activity from Northwest of Iran. Bioimpacts. 3(3): 129-134.

Mao, J., J. Wang, H. Q. Dai, Z. D. Zhang, Q. Y. Tang, B. Ren, N. Yang, M. Goodfellow, L. X. Zhang and Z. Liu. 2011. Yuhushiella deserti gen. nov., sp. nov., a new member of the suborder Pseudonocardineae. Int. J. Syst. Evol. Microbiol. 61: 621-630.

Mokrane, S., N. Bouras, N. Sabaou and F. Mathieu. 2013. Actinomycetes from saline and non-saline soils of Saharan palm groves: Taxonomy, ecology and antagonistic properties. Afr. J. Microbiol. Res. 7(20): 2167-2178.

Newman, D. J. and G. Cragg. 2007. Natural products as sources of new drugs over the last 25 years. J. Nat. Prod. 70: 461-477. 
Olsen, G. J. and C. R. Woese. 1993. Ribosomal RNA: A key to phylogeny. FASEB J. 7: 113-123.

Omura, S. 1992. Theexpandedhorizonformicrobialmetabolites areview. Gene. 115: 141-149.

Pitcher, D. G., N. A. Saunders and R. Owen. 1989. Rapid extraction of bacterial genomic DNA with guanidium thiocyanate. Lett. Appl. Microbiol. 8: 151-156.

Reed, J. F. and R. Cumming. 1945. Soil reaction glass electrodes and calorimetric methods for determining $\mathrm{pH}$ value of soil. Soil Sci. 59: 97-104.

Saitou, N. and M. Nei. 1987. The neighbor-joining method: A new method for constructing phylogenetic trees. Mol. Biol. Evol. 4: 406-425.

Sembiring, L., A. C. Ward and M. Goodfellow. 2000. Selective isolation and characterization of members of the Streptomyces violaceusniger clade associated with the roots of Paraserianthes falcataria. Antonie Van Leeuwenhoek. 78: 353-366.

Stackebrandt, E., W. Frederiksen, G. M. Garrity, P. A. Grimont, P. Kampfer, M. C. Maiden, X. Nesme, R. Rossello-Mora, J. Swings, H. G. Truper, L. Vauterin, D. A. C. War and W. Whitman. 2002. Report of the ad hoc committee for the reevaluation of the species definition in bacteriology. Int. J. Syst. Evol. Microbiol. 52: 1043-1047.

Tamura, K., G. Stecher, D. Peterson, A. Filipski and S. Kumar. 2013. MEGA6 : Molecular evolutionary genetics analysis version 6. 0. Mol. Biol. Evol. 30(12): 2725-2729.

Tan, G. Y. A., S. Robinson, E. Lacey and M. Goodfellow. 2006. Amycolatopsis australiensis sp. nov., an actinomycete isolated from arid soils. Int. J. Syst. Evol. Microbiol. 56: 2297-2301.
Trujillo M. E, M. Goodfellow. 2012. Haloactinospora. In: Goodfellow, M., P. Kämpfer, H. J. Busse, M. E. Trujillo, K. I. Suzuki, W. I. Ludwig and W. B. Whitman. editors. Bergey's Manual of Systematic Bacteriology. 2 ${ }^{\text {nd }}$., Vol. 5. Springer, Berlin, Germany. p519071908.

Vetsigian, K., R. Jajoo and R. Kishony. 2011. Structure and evolution of Streptomyces interaction networks in soil and in silico. PLoS Biol. 9(10): 1-12.

Vickers, J. C., S. T. Williams and G. Ross. 1984. A taxonomic approach to selective isolation of Streptomyces. Biol. Biochem. Biomed. Aspects Actinomycetes. 1: 553-561.

Waksman, S. A. and A. T. Henrici. 1943. The nomenclature and classification of the actinomycetes. J. Bacteriol. 46: 337-341.

Watkins. 2013. Factors Influencing the Distribution of Soil Streptomyces spp. and Determination of Species Capable of Producing a Neurodegenerative Metabolite. The University of Albama, Alabama.

Williams, S. T., M. Goodfellow, G. Alderson, E. M. H. Wellington, P. H. A. Sneath and M. J. Sackin. 1983. Numerical classification of Streptomyces and related genera. J. Gen. Microbiol. 129: 1743-1813.

Witt, D. and E. Stackebrandt. 1990. Unification of the genera streptoverticillium and Streptomyces, and amendation of Streptomyces Waksman and Henrici 1943, 339AL. Syst. Appl. Microbiol. 13: 361-371.

Yousif, G., K. Busarakam and B. K. M. Goodfellow. 2015. Streptomyces mangrovi sp. nov., isolated from mangrove forest sediment. Antonie van Leeuwenhoek. 108(3): 783-791. 